\title{
Nanostructured CuO Thin Films Prepared through Sputtering for Solar Selective Absorbers
}

\author{
Senthuran Karthick Kumar, ${ }^{1}$ Sepperumal Murugesan, ${ }^{2}$ \\ Santhanakrishnan Suresh, ${ }^{1}$ and Samuel Paul Raj ${ }^{1}$ \\ ${ }^{1}$ School of Energy, Environment and Natural Resources, Madurai Kamaraj University, Madurai 625 021, India \\ ${ }^{2}$ School of Chemistry, Madurai Kamaraj University, Madurai 625 021, India
}

Correspondence should be addressed to Sepperumal Murugesan; smsan03@yahoo.co.uk

Received 28 April 2013; Revised 31 August 2013; Accepted 31 August 2013

Academic Editor: Xin Wang

Copyright ( 2013 Senthuran Karthick Kumar et al. This is an open access article distributed under the Creative Commons Attribution License, which permits unrestricted use, distribution, and reproduction in any medium, provided the original work is properly cited.

\begin{abstract}
Nanostructured cupric oxide $(\mathrm{CuO})$ thin films have been deposited on copper $(\mathrm{Cu})$ substrates at different substrate temperatures and oxygen to argon gas ratios through direct current (DC) reactive magnetron sputtering. The deposited CuO thin films are characterized by using X-ray diffraction (XRD), scanning electron microscopy (SEM), energy dispersive spectroscopy (EDS), profilometry, and spectrophotometry techniques. The crystalline phases, morphology, optical properties, and photothermal conversion efficiency of the $\mathrm{CuO}$ thin films are found to be significantly influenced by the change in substrate temperature and oxygen to argon gas ratio. The variations in the substrate temperature and oxygen to argon gas ratio have induced changes in $\mathrm{Cu}^{+}$ and $\mathrm{Cu}^{2+}$ concentrations of the $\mathrm{CuO}$ thin films that result in corresponding changes in their optical properties. The $\mathrm{CuO}$ thin film prepared at a substrate temperature of $30^{\circ} \mathrm{C}$ and $\mathrm{O}_{2}$ to Ar gas ratio of $1: 1$ has exhibited high absorptance and low emittance; thus, it could be used as a solar selective absorber in solar thermal gadgets.
\end{abstract}

\section{Introduction}

Solar collectors have gained immense interest owing to their potential applications in the field of water and air heating systems and cooling of buildings [1]. A thin film coated on a metal substrate having selective spectral response in the solar radiation is called selective coating. An ideal selective coating should have high solar absorptance $(\alpha)$ in the visible and near infrared region $(0.3-2 \mu \mathrm{m})$ and low thermal emittance $(\varepsilon)$ in the infrared region $(2-20 \mu \mathrm{m})$ of the solar spectrum in order to fully utilize the high energy radiation as well as to minimize undesired thermal losses $[2,3]$. Hence, the effective use of solar energy for thermal applications requires the development of optically efficient solar selective coatings. The economic viability of the conversion process of solar energy into thermal energy depends on low-cost production and high durability of the selective coating under severe operational conditions along with efficient collection of solar radiation [4]. In this connection, several solar selective coatings have been developed in order to use them as selective absorbers in flat-plate collectors.

Cupric oxide $(\mathrm{CuO})$ is a p-type semiconductor with bandgap energy of $1.2 \mathrm{eV}$ [5]. It has been widely investigated for various applications such as solar energy conversion, optoelectronics, batteries, sensors, semiconductors, and catalysis $[6,7]$. The nontoxicity of $\mathrm{CuO}$ and abundant availability of its constituents make it an advantageous and promising material for device applications [8]. Apart from its promising role as a semiconductor material in solar cells (due to its appropriate optical properties), $\mathrm{CuO}$ is an attractive candidate as a solar selective absorber because of its high solar absorptance and low thermal emittance at the normal operating temperatures [4].

Different methods, such as, thermal oxidation [9], electro deposition [10], chemical conversion [11], spray-pyrolysis [12], chemical vapour deposition [13], and reactive sputtering [14], have been investigated towards the preparation of solar selective absorber coatings. Among them, direct current 
(DC) reactive magnetron sputtering is regarded as one of the best techniques because of its advantageous features of controlling the chemical composition, film thickness, high deposition rates, and low substrate heating during the deposition of thin films [15]. In DC reactive magnetron sputtering, the physical properties of the deposited films critically depend on sputtering parameters, such as, oxygen partial pressure, sputtering pressure, substrate temperature, sputtering power, and distance between the target and the substrate. In this work, the $\mathrm{CuO}$ thin films were prepared on $\mathrm{Cu}$ substrate through $\mathrm{DC}$ reactive magnetron sputtering technique, and the influences of substrate temperature and oxygen partial pressure on the morphology, crystalline phases, optical properties, and photothermal performance of the resultant $\mathrm{CuO}$ thin films were investigated.

\section{Materials and Methods}

2.1. Preparation of $\mathrm{CuO}$ Thin Films. Copper oxide $(\mathrm{CuO})$ thin films were deposited on copper substrate $(\mathrm{Cu})$ by $\mathrm{DC}$ reactive magnetron sputtering technique. High purity $\mathrm{Cu}$ plate with $50.8 \mathrm{~mm}$ diameter and $3 \mathrm{~mm}$ thickness was used as the target substrate. Argon (Ar) and oxygen $\left(\mathrm{O}_{2}\right)$ were used as sputtering and reactive gases, respectively. When the sputtering chamber reached the required deposition pressure of $6.3 \times 10^{-3}$ Torr, the DC power supply was turned on at $90 \mathrm{~W}$ to start the thin film deposition. The sputtering duration was $20 \mathrm{~min}$ in all the cases. The $\mathrm{O}_{2}$ to $\mathrm{Ar}$ gas flow ratios were maintained at $1: 1$ and $1: 2$, and the substrate temperatures were fixed at $30^{\circ} \mathrm{C}$ (room temperature) and $300^{\circ} \mathrm{C}$ during sputtering deposition of $\mathrm{CuO}$ thin films.

2.2. Characterization. X-ray diffraction (XRD) patterns of the prepared $\mathrm{CuO}$ thin film samples were recorded on a Bruker AXS D8 Advance X-ray diffractometer with $\mathrm{Cu}$ $\mathrm{K} \alpha$ radiation $(\lambda=1.5418 \AA)$. Scanning electron microscopic (SEM) images were recorded using JEOL Model 6390 scanning electron microscope fitted with an energy dispersive spectroscopy (EDS) accessory. Thicknesses of the deposited $\mathrm{CuO}$ thin films were determined by a profilometer. Normal reflectance of the prepared samples were measured in the wavelength range of $0.3-0.8 \mu \mathrm{m}$ using a UVvis spectrophotometer (SHIMADZU UV-2550) equipped with diffuse reflectance spectral accessory (ISR-2200). The reflectance in the IR region $(2.5-25 \mu \mathrm{m})$ was measured using Nexus 670 Fourier transform infrared spectrophotometer. The solar absorptance was calculated, according to ISO 9845-1 procedure, by the weighted integration of the spectral reflectance with the hemispherical solar spectrum of AM 1.5. The thermal emittance was evaluated by the weighted integration of the spectral reflectance with Planck's black body radiation distribution at $373 \mathrm{~K}$ [16].

The solar absorptance of a solar collector surface is defined as the fraction of radiation incident on the surface of

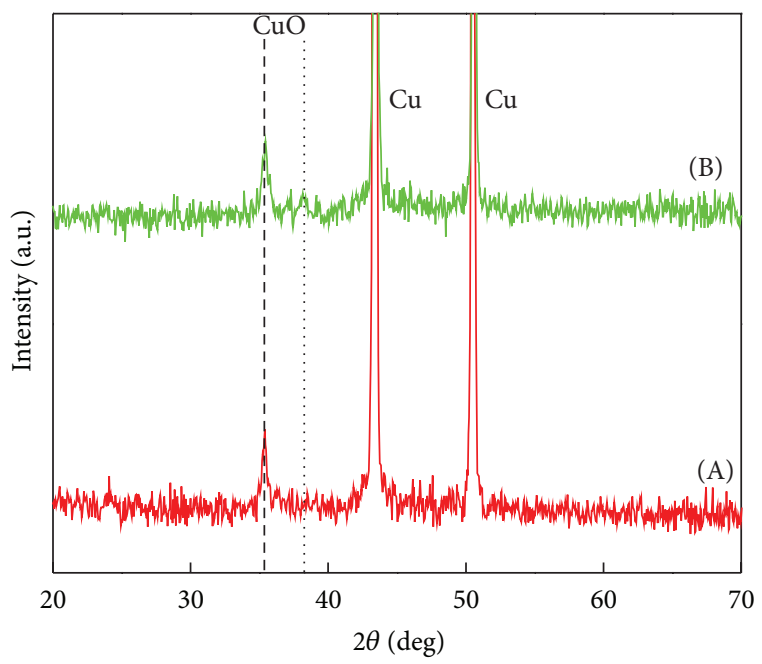

FIGURE 1: XRD patterns of $\mathrm{CuO}$ thin films prepared at room temperature with oxygen to argon ratios of $1: 1(\mathrm{~A})$ and $2: 1(\mathrm{~B})$.

the material that is absorbed. It is a function of the materials reflectance $R(\lambda)$ and is given by

$$
\text { Absorptance }(\alpha)=\frac{\int_{0.3 \mu \mathrm{m}}^{0.8 \mu \mathrm{m}} I_{\text {sol }}(\lambda)(1-R(\lambda) d \lambda)}{\int_{0.3 \mu \mathrm{m}}^{0.8 \mu \mathrm{m}} I_{\text {sol }}(\lambda) d \lambda} \text {, }
$$

where $I_{\text {sol }}(\lambda)$ is the normal spectral irradiance of solar radiation at the wavelength $(\lambda)$.

The fractional emittance may be defined as the weighted fraction (by total power density) of the emitted radiation:

$$
\text { Emittance }(\varepsilon)=\frac{\int_{2.5 \mu \mathrm{m}}^{20 \mu \mathrm{m}} \rho(\lambda)(1-R(\lambda) d \lambda)}{\int_{2.5 \mu \mathrm{m}}^{20 \mu \mathrm{m}} \rho(\lambda) d \lambda},
$$

where $\rho(\lambda)$ is the spectral irradiance of a black body at the temperature $(T)$.

The selectivity $(\xi)$ of a solar-selective absorber coating is given as the ratio of solar absorptance $(\alpha)$ to thermal emittance $(\varepsilon)$. That is,

$$
\xi=\frac{\alpha}{\varepsilon}
$$

\section{Results and Discussion}

3.1. XRD Studies. Figure 1 shows the XRD patterns of the $\mathrm{CuO}$ thin films prepared at room temperature by $\mathrm{DC}$ reactive magnetron sputtering under oxygen to argon gas flow ratios of $1: 1$ and $2: 1$. The XRD patterns reveal that the prepared thin films are polycrystalline in nature. As can be seen from Figure 1(A), the thin film deposited with oxygen to argon gas ratio of $1: 1$ shows a diffraction peak at $2 \theta$ value of $35.5^{\circ}$ corresponding to the $\left(\begin{array}{lll}0 & 0 & 2\end{array}\right)$ plane of end-centered monoclinic structured $\mathrm{CuO}$. The highly intense diffraction peaks observed at $2 \theta$ values of 43.3 and $50.48^{\circ}$ can be attributed to the (llll 111$)$ and ( $\left.\begin{array}{lll}2 & 0 & 0\end{array}\right)$ planes of face-centered 


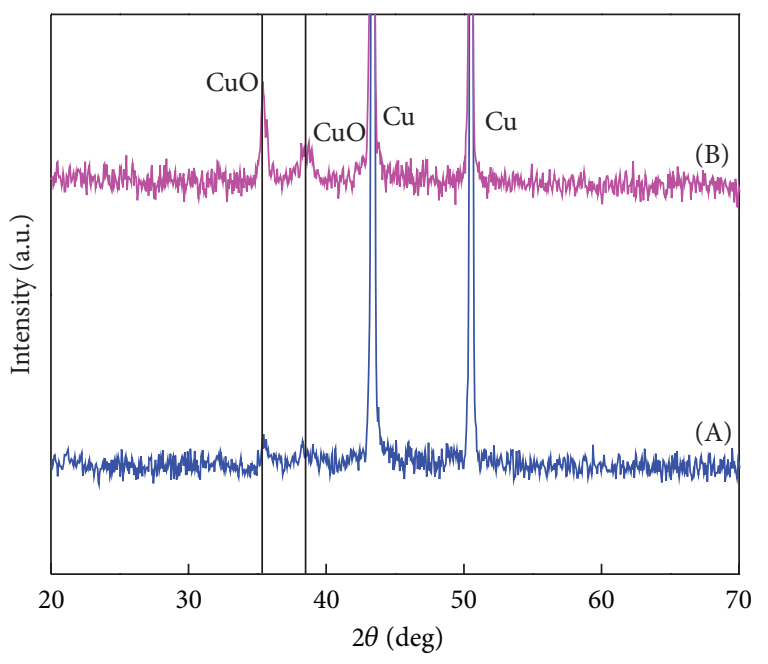

FIGURE 2: XRD patterns of the $\mathrm{CuO}$ thin films sputtered at substrate temperature of $300^{\circ} \mathrm{C}$ with $\mathrm{O}_{2}$ to Ar gas ratios of $1: 1$ (A) and $2: 1(\mathrm{~B})$.

cubic (FCC) structured Cu (JCPDS No. 04-0836) substrate (unoxidized $\mathrm{Cu}$ substrate present underneath the $\mathrm{CuO}$ thin film). The existence of meager proportion of $\mathrm{Cu}_{2} \mathrm{O}$ is also confirmed as the low intense peaks appearing at $2 \theta$ values of 36.5 and $42.4^{\circ}$ correspond to the diffraction lines produced by $\left(\begin{array}{lll}1 & 1 & 1\end{array}\right)$ and $\left(\begin{array}{lll}2 & 0 & 0\end{array}\right)$ planes of $\mathrm{Cu}_{2} \mathrm{O}$ (JCPDS Card no. 653288). The presence of a mixed phase of $\mathrm{CuO}$ and $\mathrm{Cu}_{2} \mathrm{O}$ is due to the partial oxidation of $\mathrm{Cu}$ substrate in the low $\mathrm{O}_{2}$ atmosphere $\left(\mathrm{O}_{2}: \mathrm{Ar}=1: 1\right)$ during sputter deposition. When the oxygen to argon ratio was increased to $2: 1$, the XRD pattern of the prepared thin film exhibited two main peaks at 35.5 and $38.7^{\circ}$, which are corresponding to the diffraction lines produced by the end-centered monoclinic structured $\mathrm{CuO}$ (JCPDS Card no. 80-1917). The observed decrease in the intensity of the peaks related to $\mathrm{Cu}\left(43.3\right.$ and $\left.50.48^{\circ}\right)$ indicates the conversion of more metallic $\mathrm{Cu}$ into $\mathrm{CuO}$ in the $\mathrm{O}_{2}$ enriched environment.

Figure 2 shows the $\mathrm{XRD}$ patterns of the $\mathrm{CuO}$ thin films sputtered at substrate temperature of $300^{\circ} \mathrm{C}$ under $\mathrm{O}_{2}$ to $\mathrm{Ar}$ gas ratios of $1: 1$ and $2: 1$. The intensities of the diffraction peaks at $2 \theta=35.5$ and $38.7^{\circ}$ are higher for the $\mathrm{CuO}$ thin films sputtered at $300^{\circ} \mathrm{C}$ when compared to the $\mathrm{CuO}$ thin films prepared at room temperature which suggests that increasing the substrate temperature promotes transformation of more metallic $\mathrm{Cu}$ into $\mathrm{CuO}$. Thus, when the coatings are deposited under low oxygen concentration, both oxides formed albeit $\mathrm{CuO}$ prevailed. Films deposited at $300^{\circ} \mathrm{C}$ and at the same $\mathrm{O}_{2} /$ Ar ratio showed more $\mathrm{CuO}$ stemming from the oxidation of the substrate copper. Overall, the XRD results reveal that the films change from low cubic $\mathrm{Cu}$ phase into monoclinic $\mathrm{CuO}$ phase with increasing oxygen concentration and substrate temperature. From the profilometer measurement, the thicknesses of the $\mathrm{CuO}$ thin films prepared were found to be $\sim 1 \mu \mathrm{m}$. It is to be noted that the thickness of the films did not change with $\mathrm{O}_{2} /$ Ar ratio or substrate temperature.

The crystallite sizes of the deposited $\mathrm{CuO}$ thin films were calculated by Scherrer's formula using the full width at half maximum (FWHM) data of the XRD peaks. The FWHM of the $\mathrm{CuO}$ diffraction peak increased from 0.69 to $0.89^{\circ}$ when the substrate temperature was increased from $30^{\circ} \mathrm{C}$ to $300^{\circ} \mathrm{C}$. This suggests that the crystallite size of the $\mathrm{CuO}$ decreases if the substrate temperature is increased. The crystallite size of the $\mathrm{CuO}$ thin films prepared at $30^{\circ} \mathrm{C}$ and $300^{\circ} \mathrm{C}$ is found to be $15 \mathrm{~nm}$ and $10 \mathrm{~nm}$, respectively. The above results indicate that the crystallite size of the films can be controlled by adjusting the substrate temperature.

3.2. SEM Analysis. The surface morphology of the $\mathrm{CuO}$ thin films was examined through scanning electron microscopic (SEM) images (Figure 3). It can be observed from the SEM images that the morphology of the $\mathrm{CuO}$ thin films is significantly influenced by the change in the operational parameters during sputtering deposition. The $\mathrm{CuO}$ thin film prepared at a substrate temperature of $30^{\circ} \mathrm{C}$ with $\mathrm{O}_{2}$ to Ar gas flow ratio of 1:1 exhibits irregular sky clouds like $\mathrm{CuO}$ nanostructures with different sizes which are entirely covered on the $\mathrm{Cu}$ substrate (Figure 3(a)). When the $\mathrm{O}_{2}$ to Ar gas flow ratio was changed to 2:1 (keeping substrate temperature at $30^{\circ} \mathrm{C}$ ), the thin film made of large number of spherical shaped granular $\mathrm{CuO}$ nanoparticles with clear grain boundaries and size ranges between 20 and $30 \mathrm{~nm}$, which are uniformly distributed on the whole $\mathrm{Cu}$ substrate, is formed (Figure 3(b)). This indicates that increasing the $\mathrm{O}_{2}$ proportion in the gas flow during sputtering deposition has the tendency to regulate the particles shape. The $\mathrm{CuO}$ thin film prepared at a substrate temperature of $300^{\circ} \mathrm{C}$ with $\mathrm{O}_{2}$ to $\mathrm{Ar}$ gas ratio of $1: 1$ possesses spherical granular $\mathrm{CuO}$ nanoparticles with size ranges from 15 to $20 \mathrm{~nm}$ (Figure 3(c)). This reveals that the increase in the substrate temperature can also regulate the $\mathrm{CuO}$ particles shape to a considerable extent even in the presence of low $\mathrm{O}_{2}$ atmosphere during sputtering deposition. On increasing the $\mathrm{O}_{2}$ proportion in the gas flow at substrate temperature of $300^{\circ} \mathrm{C}$, the resultant $\mathrm{CuO}$ thin film contained smaller sized $(\sim 10 \mathrm{~nm})$ spherical shaped $\mathrm{CuO}$ nanoparticles, which are homogeneously packed on the whole $\mathrm{Cu}$ substrate (Figure 3(d)). Thus, at elevated temperatures, high $\mathrm{O}_{2}$ content in the gas flow during the sputtering deposition regulates the particles shape as well as particles size of $\mathrm{CuO}$, and thereby forming a uniform film with small sized grains. Similar morphology has been observed for the $\mathrm{CuO}$ thin films deposited via sol gel route [7], which indicates that the formation of spherical nanoparticles is inherent property of the $\mathrm{CuO}$ coating irrespective of the deposition methods.

The EDS spectra of $\mathrm{CuO}$ thin film samples (Figure 4) clearly demonstrate the presence of only peaks corresponding to $\mathrm{Cu}$ and $\mathrm{O}$ elements. The observed atomic ratio of $2: 1$ between $\mathrm{Cu}$ and $\mathrm{O}$ elements suggests the presence of $\mathrm{Cu}_{2} \mathrm{O}$ in these films. But, the XRD results suggested that the films predominantly contain $\mathrm{CuO}$. The XRD patterns also contain the peaks corresponding to metallic $\mathrm{Cu}$ originating from $\mathrm{Cu}$ substrate as the films are thin. Thus the excess $\mathrm{Cu}$ observed in EDS is originating from $\mathrm{Cu}$ substrate. There were no peaks related to the elements other than $\mathrm{Cu}$ and $\mathrm{O}$ in the EDS spectra, which revealed the formation of phase pure $\mathrm{CuO}$ in the thin films prepared through sputtering 


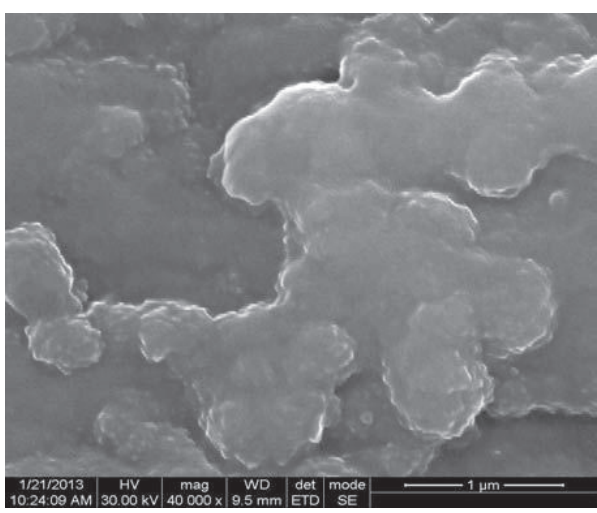

(a)

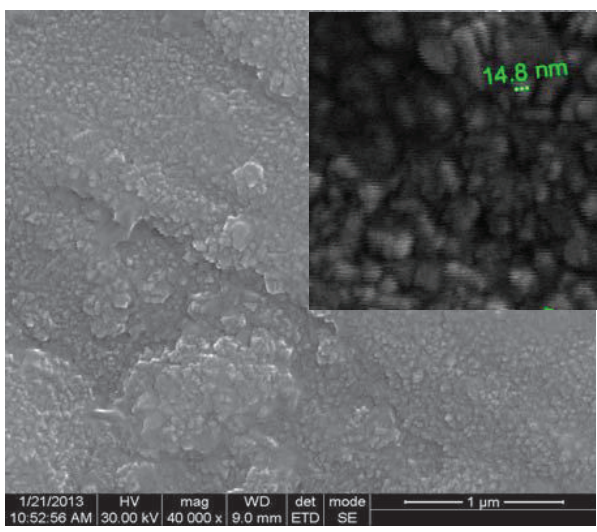

(c)

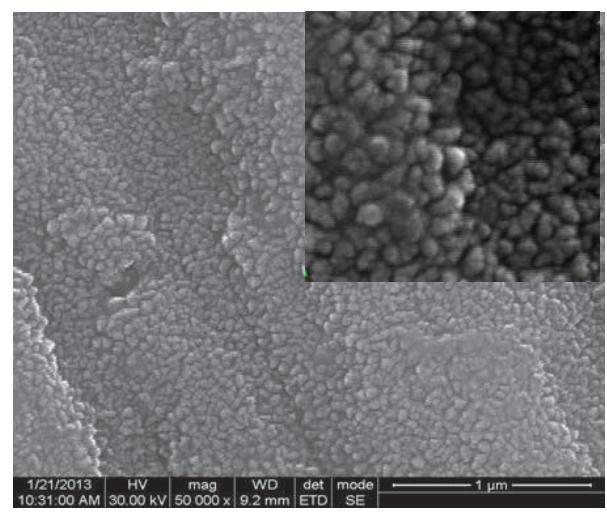

(b)

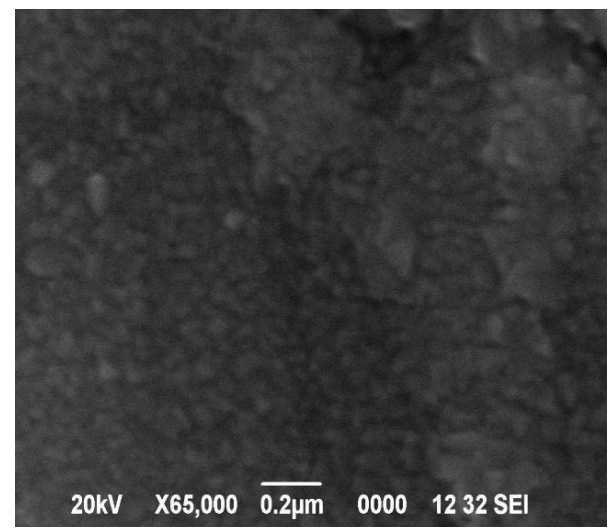

(d)

Figure 3: SEM images of $\mathrm{CuO}$ thin films prepared at room temperature, with oxygen to argon ratios of $1: 1$ (a) and $2: 1$ (b), and at substrate temperature $300^{\circ} \mathrm{C}$ with oxygen to argon ratios of $1: 1(\mathrm{c})$ and $2: 1(\mathrm{~d})$.

deposition technique. The $\mathrm{XRD}$ results already revealed that the prepared $\mathrm{CuO}$ thin film samples have only monoclinic $\mathrm{CuO}$.

3.3. Optical Properties. The UV-visible reflectance spectra of the DC reactive magnetron sputtered copper oxide thin films were recorded in the wavelength range between 200 and $900 \mathrm{~nm}$ (Figure 5). The reflectance spectra of all the copper oxide thin films do not possess any dissimilar variations in the wavelength range between 300 and $550 \mathrm{~nm}$ which clearly demonstrate that all the four copper oxide thin films are made up of $\mathrm{CuO}$ only and not with $\mathrm{Cu}_{2} \mathrm{O}$ [17]. Even though the XRD results of the copper oxide thin films sputtered at room temperature have explicated the presence of $\mathrm{Cu}_{2} \mathrm{O}$, the small proportion of $\mathrm{Cu}_{2} \mathrm{O}$ present in the thin films might not contribute enough to delivering its characteristic reflectance behavior. All the $\mathrm{CuO}$ thin films exhibit reflectivity values close to each other in the wavelength range between 200 and $600 \mathrm{~nm}$. However, they show abrupt variations in the reflectance in the higher wavelength region (600 to $900 \mathrm{~nm}$ ) which can be attributed to the morphological and roughness dependent multiple absorption and reflectance caused by the different $\mathrm{CuO}$ thin films. Particularly, the $\mathrm{CuO}$ thin films prepared at substrate temperature of $30^{\circ} \mathrm{C}$ maintains their low reflectance behavior up to $900 \mathrm{~nm}$ while the $\mathrm{CuO}$ thin films prepared at substrate temperature of $300^{\circ} \mathrm{C}$ show high reflectance above $700 \mathrm{~nm}$. The results of the reflectance study indicate that the $\mathrm{CuO}$ thin films prepared at the substrate temperature of $30^{\circ} \mathrm{C}$ possess strong visible light absorption than the samples prepared at the substrate temperature of $300^{\circ} \mathrm{C}$, and thus the former films are ideal solar selective absorbers.

The lower IR transmittance profile of these thin films (Figure 6) may also be due to the scattering effect of light through the optically anisotropic monoclinic structured $\mathrm{CuO}$ thin films. The values of solar absorptance were calculated from the spectral reflectance by using the spectral irradiance of the sun for zero air mass, and values of the thermal emittance were calculated by using Planck's spectral distribution of emissive power (at $100^{\circ} \mathrm{C}$ ). Table 1 shows the solar absorptance, thermal emittance, and selectivity values of the polycrystalline $\mathrm{CuO}$ thin films deposited on a copper substrate through magnetron sputtering technique. The emissivities of nanostructured $\mathrm{CuO}$ thin films are small as well as very close to each other, which can be ascribed to the high degree of thermal scattering that takes place within the $\mathrm{CuO}$ thin films made of nanosized grains. The $\mathrm{CuO}$ thin film with sky cloud-like morphology demonstrate high solar absorptance (0.71) coupled with low infrared emittance (0.07) and thus high solar selectivity (10.1) which are essential for 


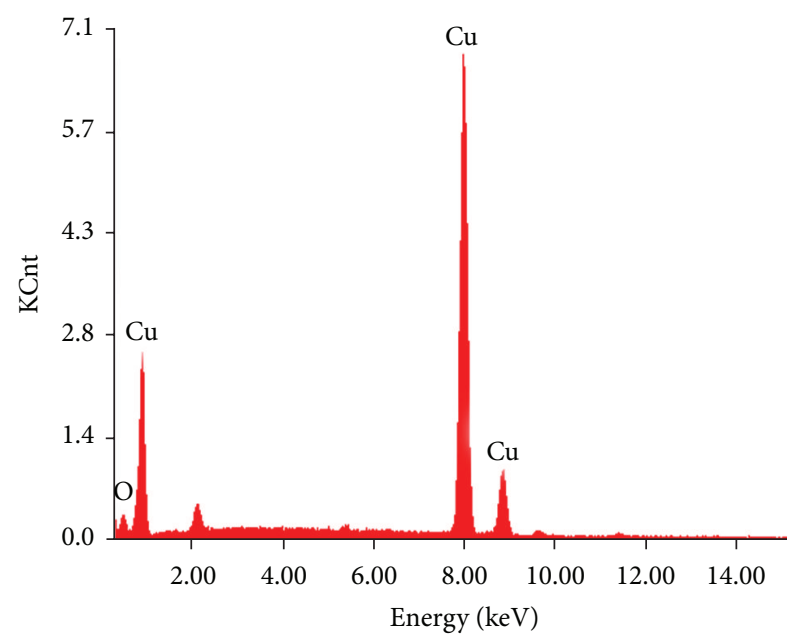

(a)

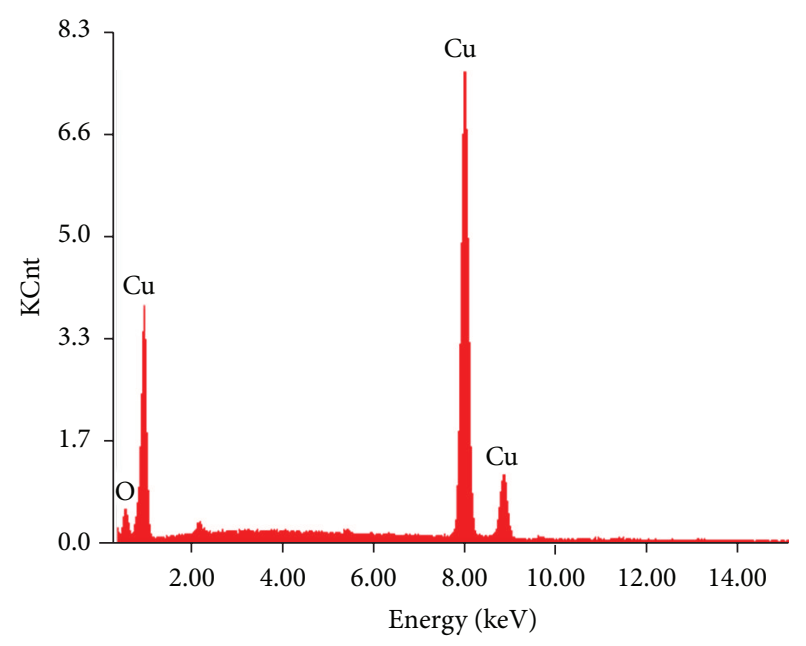

(b)

FIGURE 4: EDS spectra of $\mathrm{CuO}$ thin films prepared at substrate temperature of $30^{\circ} \mathrm{C}(\mathrm{a})$ and $300^{\circ} \mathrm{C}(\mathrm{b})$ with oxygen to argon gas ratio of $2: 1$.

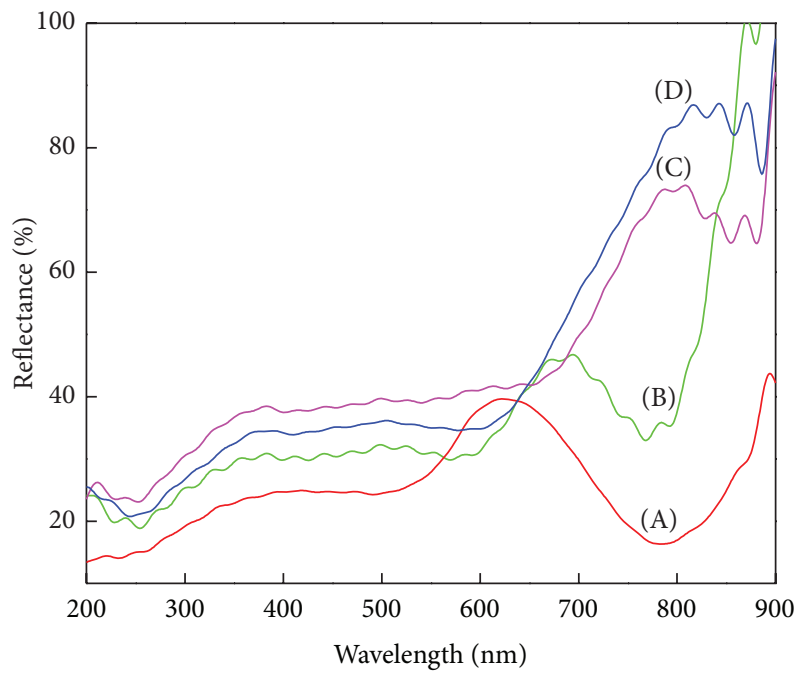

FIGURE 5: UV-vis reflectance spectra of $\mathrm{CuO}$ thin films prepared at room temperature (with oxygen to argon gas flow ratios of $1: 1$ (A) and $2: 1(\mathrm{~B})$ ) and at a substrate temperature of $300^{\circ} \mathrm{C}$ (with oxygen to argon gas flow ratios of $1: 1(\mathrm{C})$ and $2: 1(\mathrm{D}))$.

solar selective absorbers towards efficient conversion of solar energy into thermal energy.

The thermal stability of a solar thermal absorber is an important characteristic that determines the durability of selective coatings at higher operating temperatures. To study the thermal stability, the reflectance of the $\mathrm{CuO}$ thin film (having best absorptance; sample A) was measured after annealing it at different temperatures, namely, 200, 250, 300, and $350^{\circ} \mathrm{C}$, for $2 \mathrm{~h}$ in a muffle furnace (same film was used consecutively). The absorptance values evaluated from the UV-vis reflectance spectra obtained after each heat treatment are given in Table 2 . It can be seen from the Table 2 that annealing at $250^{\circ} \mathrm{C}$ does not change the absorptance of the film much while the absorptance significantly reduced after

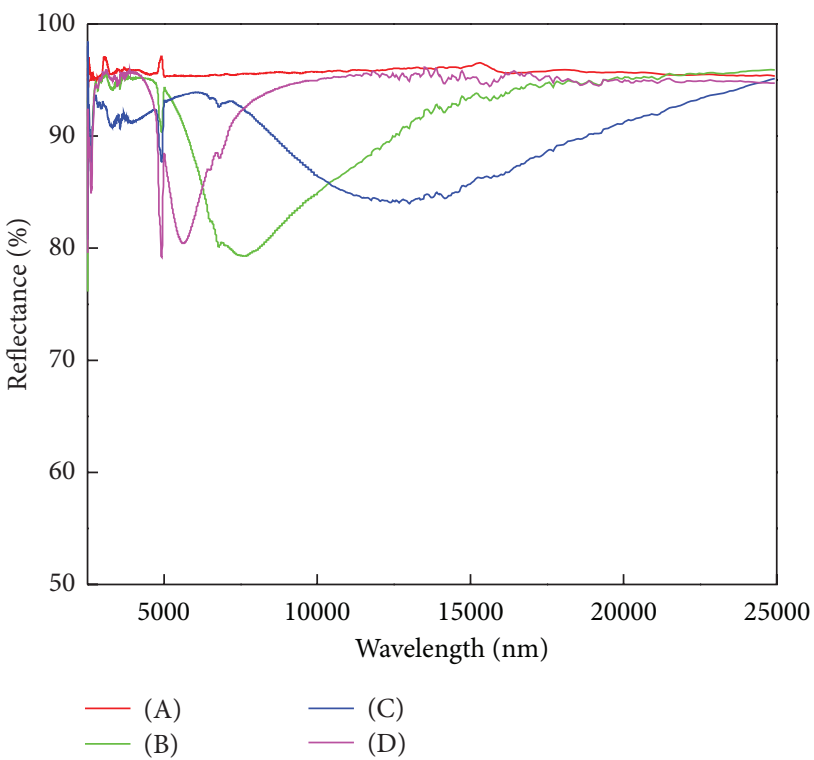

FIGURE 6: IR reflectance spectra of $\mathrm{CuO}$ thin films prepared at room temperature (with oxygen to argon gas flow ratios of $1: 1$ (A) and $2: 1$ (B)) and at a substrate temperature of $300^{\circ} \mathrm{C}$ (with oxygen to argon gas flow ratios of $1: 1(\mathrm{C})$ and $2: 1(\mathrm{D}))$.

heat treatment at $300^{\circ} \mathrm{C}$ and $350^{\circ} \mathrm{C}$. These results suggest that the $\mathrm{CuO}$ thin film prepared through room temperature sputtering is stable in air up to $250^{\circ} \mathrm{C}$ operating temperatures without any significant loss in their absorptance values.

\section{Conclusions}

Nanostructured cupric oxide $(\mathrm{CuO})$ thin films were deposited on copper $(\mathrm{Cu})$ substrates through DC reactive magnetron sputtering of pure copper target at two different substrate temperatures. The crystalline phases, morphology, 
TABle 1: Photo-thermal performance of different $\mathrm{CuO}$ thin films prepared though DC reactive magnetron sputtering.

\begin{tabular}{lccccc}
\hline Sample & $\begin{array}{c}\text { Substrate } \\
\text { temp. }\left({ }^{\circ} \mathrm{C}\right)\end{array}$ & $\begin{array}{c}\mathrm{O}_{2} \text { to } \\
\text { Ar ratio }\end{array}$ & $\begin{array}{c}\text { Absorptance } \\
(\alpha)\end{array}$ & $\begin{array}{c}\text { Emittance } \\
(\varepsilon)\end{array}$ & $\begin{array}{c}\text { Selectivity } \\
(\alpha / \varepsilon)\end{array}$ \\
\hline $\mathrm{A}$ & 30 & $1: 1$ & 0.71 & 0.07 & 10.1 \\
$\mathrm{~B}$ & 30 & $1: 2$ & 0.66 & 0.09 & 7.3 \\
$\mathrm{C}$ & 300 & $1: 1$ & 0.57 & 0.10 & 5.7 \\
$\mathrm{D}$ & 300 & $1: 2$ & 0.56 & 0.09 & 6.2 \\
\hline
\end{tabular}

TABLE 2: The absorptance values of $\mathrm{CuO}$ thin films prepared through room temperature sputtering after $2 \mathrm{~h}$ annealing at various temperatures.

\begin{tabular}{ccc}
\hline Sample & Annealing temperature $\left({ }^{\circ} \mathrm{C}\right)$ & Absorptance $(\alpha)$ \\
\hline \multirow{3}{*}{ A } & 200 & 0.71 \\
& 250 & 0.69 \\
& 300 & 0.51 \\
& 350 & 0.45 \\
\hline
\end{tabular}

and optical properties of the $\mathrm{CuO}$ thin films are directly influenced by change in the substrate temperature and oxygen $\left(\mathrm{O}_{2}\right)$ to argon (Ar) gas flow ratio. Moreover, the substrate temperature and $\mathrm{O}_{2}$ to $\mathrm{Ar}$ gas flow ratio induced changes in $\mathrm{Cu}^{+}$and $\mathrm{Cu}^{2+}$ concentrations of the thin films that led to the corresponding changes in their optical properties. The Xray diffraction (XRD) study indicated that the formed $\mathrm{CuO}$ thin films are polycrystalline in nature. Elevated temperature and high $\mathrm{O}_{2}$ to Ar gas flow ratio favour the formation of smooth films with small sized $\mathrm{CuO}$ grains. The $\mathrm{CuO}$ thin film prepared at a substrate temperature of $30^{\circ} \mathrm{C}$ and $\mathrm{O}_{2}$ to $\mathrm{Ar}$ gas flow ratio of $1: 1$ exhibited high solar absorptance (0.71) and low emittance (0.07), which indicate that it can be integrated as selective absorber in solar thermal gadgets.

\section{Acknowledgment}

The authors thank the UGC, New Delhi, for the financial support under the University with Potential for Excellence (UPE) scheme.

\section{References}

[1] K. D. Lee, W. C. Jung, and J. H. Kim, "Thermal degradation of black chrome coatings," Solar Energy Materials and Solar Cells, vol. 63, no. 2, pp. 125-137, 2000.

[2] N. C. Bhowmik, J. Rahman, M. A. A. Khan, and Z. H. Mazumder, "Preparation of selective surfaces and determination of optimum thickness for maximum selectivity," Renewable Energy, vol. 24, no. 3-4, pp. 663-666, 2001.

[3] D. Katzen, E. Levy, and Y. Mastai, "Thin films of silica-carbon nanocomposites for selective solar absorbers," Applied Surface Science, vol. 248, no. 1-4, pp. 514-517, 2005.

[4] J. Vince, A. Šurca Vuk, U. Opara Krašovec, B. Orel, M. Köhl, and M. Heck, "Solar absorber coatings based on CoCuMnOx spinels prepared via the sol-gel process: structural and optical properties," Solar Energy Materials and Solar Cells, vol. 79, no. 3, pp. 313-330, 2003.
[5] H. He, P. Bourges, Y. Sidis et al., "Magnetic resonant mode in the single-layer high-temperature superconductor $\mathrm{Tl}_{2} \mathrm{Ba}_{2} \mathrm{CuO}_{6+\delta}$," Science, vol. 295, no. 5557, pp. 1045-1047, 2002.

[6] W. Jia, E. Reitz, P. Shimpi, E. G. Rodriguez, P.-X. Gao, and Y. Lei, "Spherical $\mathrm{CuO}$ synthesized by a simple hydrothermal reaction: concentration-dependent size and its electrocatalytic application," Materials Research Bulletin, vol. 44, no. 8, pp. 16811686, 2009.

[7] B. Orel, F. Švegl, N. Bukovec, and M. Kosec, "Structural and optical characterization of $\mathrm{CuO}$ particulate solid films and the corresponding gels and xerogels," Journal of Non-Crystalline Solids, vol. 159, no. 1-2, pp. 49-64, 1993.

[8] A. Y. Oral, E. Menşur, M. H. Aslan, and E. Başaran, "The preparation of copper(II) oxide thin films and the study of their microstructures and optical properties," Materials Chemistry and Physics, vol. 83, no. 1, pp. 140-144, 2004.

[9] X. Jiang, T. Herricks, and $\mathrm{Y}$. Xia, "CuO nanowires can be synthesized by heating copper substrates in air," Nano Letters, vol. 2, no. 12, pp. 1333-1338, 2002.

[10] M. Voinea, C. Vladuta, C. Bogatu, and A. Duta, "Surface properties of copper based cermet materials," Materials Science and Engineering B, vol. 152, no. 1-3, pp. 76-80, 2008.

[11] P. Richharia, K. L. Chopra, and M. C. Bhatnagar, "Surface analysis of a black copper selective coating," Solar Energy Materials, vol. 23, no. 1, pp. 93-109, 1991.

[12] J. Morales, L. Sánchez, F. Martín, J. R. Ramos-Barrado, and M. Sánchez, "Use of low-temperature nanostructured $\mathrm{CuO}$ thin films deposited by spray-pyrolysis in lithium cells," Thin Solid Films, vol. 474, no. 1-2, pp. 133-140, 2005.

[13] T. Maruyama, "Copper oxide thin films prepared by chemical vapor deposition from copper dipivaloylmethanate," Solar Energy Materials and Solar Cells, vol. 56, no. 1, pp. 85-92, 1998.

[14] A. S. Reddy, H.-H. Park, V. S. Reddy et al., "Effect of sputtering power on the physical properties of dc magnetron sputtered copper oxide thin films," Materials Chemistry and Physics, vol. 110, no. 2-3, pp. 397-401, 2008.

[15] H.-C. Lu, C.-L. Chu, C.-Y. Lai, and Y.-H. Wang, "Property variations of direct-current reactive magnetron sputtered copper oxide thin films deposited at different oxygen partial pressures," Thin Solid Films, vol. 517, no. 15, pp. 4408-4412, 2009.

[16] J. A. Duffie and W. A. Beckman, Solar Engineering of Thermal Process, John Wiley \& Sons, New York, NY, USA, 1980.

[17] A. H. Jayatissa, K. Guo, and A. C. Jayasuriya, "Fabrication of cuprous and cupric oxide thin films by heat treatment," Applied Surface Science, vol. 255, no. 23, pp. 9474-9479, 2009. 


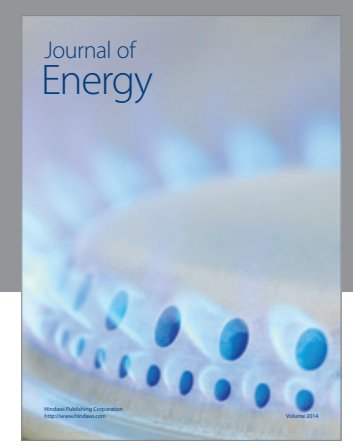

Journal of

Industrial Engineering
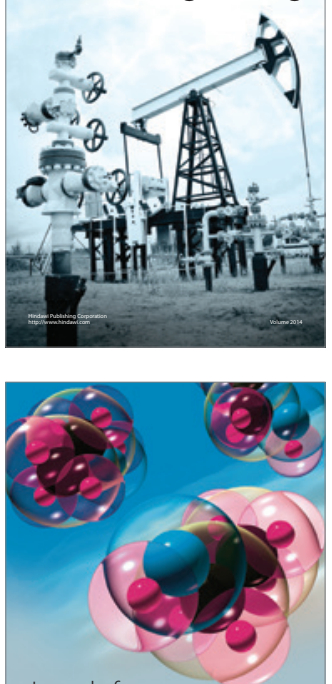

Fuels
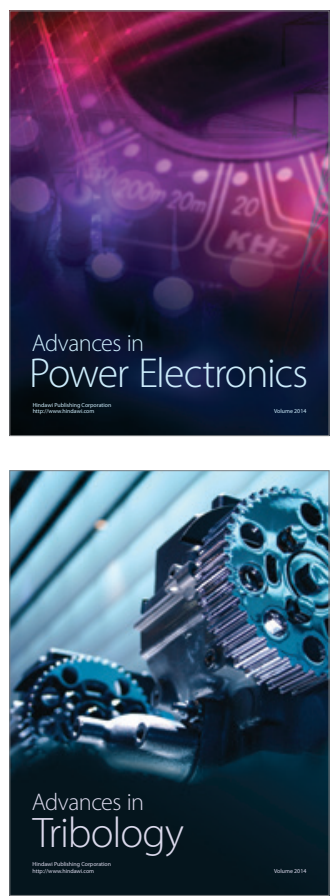

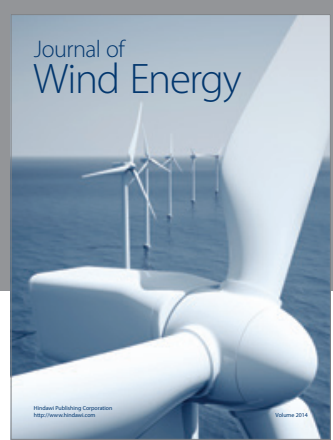

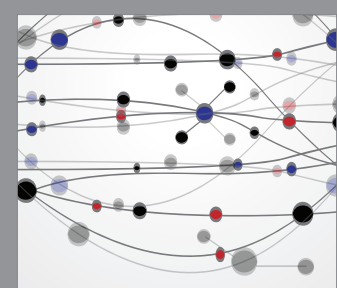

The Scientific World Journal

Submit your manuscripts at http://www.hindawi.com

Journal of

Structures
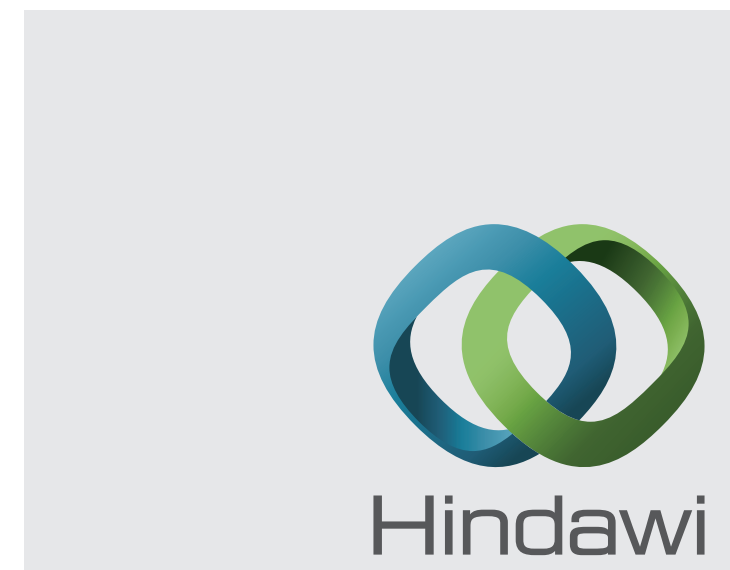

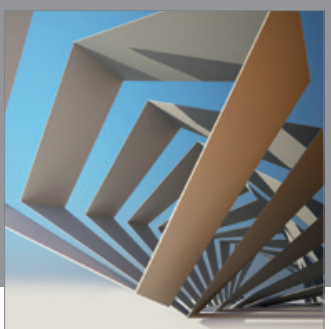

Rotating

Machinery
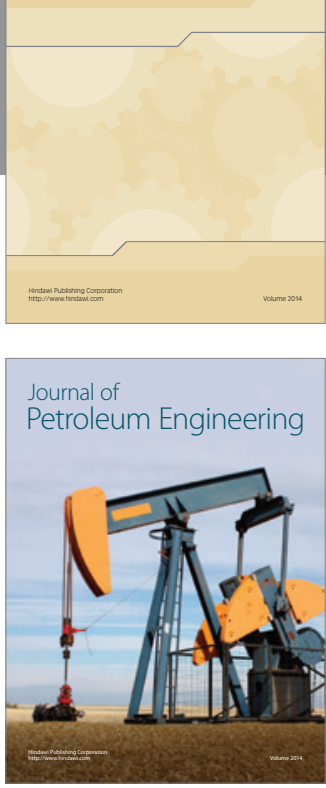

Journal of

Solar Energy
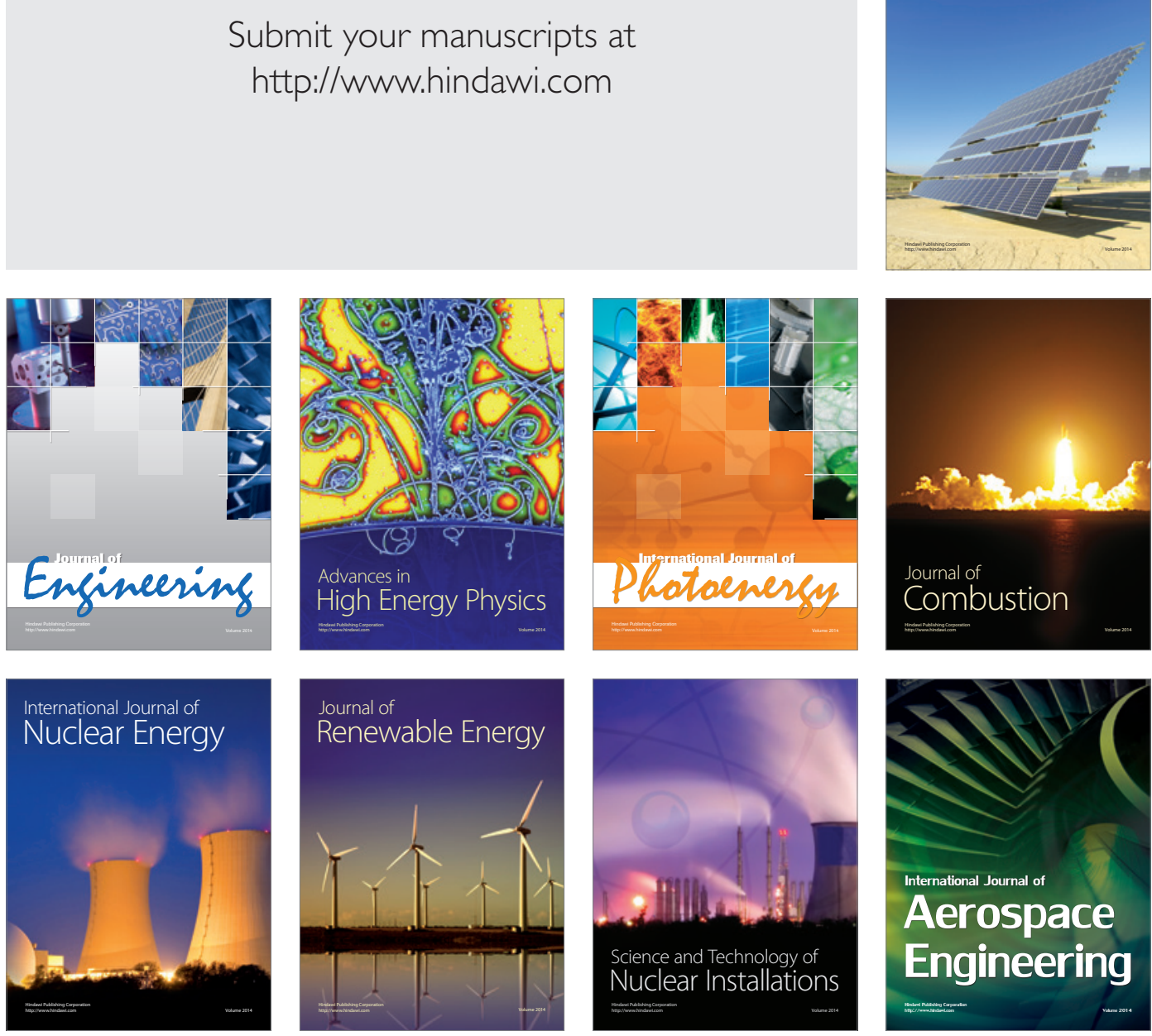